\title{
Transformation management of primary health care services in two selected local authorities in Gauteng
}

\author{
W Sibaya, M.Cur., Master student, Department of Nursing Science, RAU \\ Marie Muller, D.Cur., Professor, Department of Nursing Science, RAU
}

\section{Abstract}

The transformation of health services in South Africa today is governed by the political, policy and legislative frameworks. This article focuses on the transformation of a primary health care service within a local authority in Gauteng. The purpose with this article is to explore and describe the perceptions (expectations and fears) of selected managers employed in this primary health care service. The results are utilised to compile a strategy (framework) for transformation management and leadership within the primary health care service. A qualitative research design was utilised and the data was collected by means of individual interviews with selected managers in the service, followed by a content analysis. The expectations and fears of managers focus mainly on personnel matters, community participation/satisfaction, salaries and parity, inadequate stocks/supplies and medication, the deterioration of quality service delivery and the need for training and empowerment. These results are divided into structure, process and outcome dimensions and are embodied in the conceptual framework for the transformation and leadership strategy. It is recommended that standards for transformation management be formulated and that the quality of transformation management be evaluated accordingly.

\section{Uittreksel}

Met die nuwe politieke, beleids- en wetlike raamwerk in Suid-Afrika, is omvorming/transformasie van gesondheidsdienslewering noodsaaklik. Hierdie artikel fokus op die omvorming/transformasie van 'n primêre gesondheidsdiens in ' $n$ geselekteerde plaaslike owerheid in Gauteng. Die doel met die navorsing was om die persepsies (verwagtinge en vrese) van bestuurders werksaam in hierdie primêre gesondheidsdienste te verken en te beskryf. Vervolgens is die resultate benut om ' $n$ strategie (raamwerk) vir transformasie/omvormingsbestuur en leierskap in die primêre gesondheidsdiens op te stel. ' $n$ Kwalitatiewe navorsingstrategie is gebruik en die data is by wyse van individuele onderhoudvoering met geselekteerde bestuurders werksaam in die gesondheidsdiens versamel, gevolg deur die uitvoering van ' $n$ inhoudsontleding. Die verwagting en vrese wat deur die bestuurders ge-opper is, fokus hoofsaaklik om personeelsake, gemeenskapsdeelname/bevrediging, salarisse en pariëteit, ontoereikende voorrade/medikasie, die afname in gehalte dienslewering en die behoefte aan opleiding en bemagtiging. Hierdie resultate is verdeel in die strukturele, proses- en uitkomsdimensies en word vervat in die konseptuele raamwerk vir die strategie om veranderingsbestuur en leierskap te rig. Daar word aanbeveel dat standaarde vir transformasie/omvormingsbestuur ontwikkel word en dat die gehalte van omvormingsbestuur daarvolgens beoordeel word.

\section{Introduction}

Local authorities traditionally rendered preventative and promotive services and the provinces were responsible for the rendering of curative services. This service delivery system was fragmented due to political policies and diversification. With the new political dispensation in South Africa, transformation is necessary to counteract the duplication and fragmentation of health care services. The transformation of health services in South Africa is guided by the White Paper on the Transformation of the Health System in South Africa (South Africa, 1997), focusing on the following: equity, acceptability, accessibility, affordability, availability and appropriateness . The local authorities are involved in this process of transformation with the integration of primary health care services as a priority and by taking over some health care services that were previously rendered by the provincial au- thorities. For this process to be successful, it is important that the local authorities and the provincial departments work together and have close co-operation in order to achieve the objectives of transforming health services and bringing about equity. The process of transformation is, however, complicated with many external and internal factors impacting on this process. The process of transformation is challenging at all levels - national, provincial and local levels. A transformation management strategy is therefore necessary to facilitate this process of change in an orderly and acceptable manner. This research focuses on the process of transformation of primary health care services in two selected local authorities in Gauteng. 
The transformation of primary health care services require that local authorities have to take over certain services that have previously been offered by the provincial administrations. The local authorities have to be prepared for this take over. Any process of change/transformation could also lead to conflict and destabilisation of existing services if not managed appropriately. The following research questions are relevant: what are the expectations and fears of managers in the local authorities in relation to the process of transformation and what transformation strategy could be developed? The objectives of this research are to explore and describe the perceptions of managers in two selected local authorities in Gauteng in relation to transformation and to formulate a strategy for transformation management within the local authority.

\section{Terminology}

\section{Transformation}

Transformation is a process of planned change within a local authority, due to external and internal forces, in accordance with health policy and legislation in South Africa.

\section{Transformation management}

Transformation management is a process of strategic change management (planning, organising, directing and control) by identifying the perceptions (views, expectations and fears) of roleplayers and by strategising to meet these expectations and to counteract their fears in an acceptable and cost-effective manner to achieve a specific goal in relation to transformation.

\section{Primary health care services}

A primary health care service is the first level of health care rendered by a local authority in accordance with the authorised national, provincial and district health care policies. "Primary health care is essential health care based on practical, scientifically sound and socially acceptable methods and technology made universally accessible to individuals and families in the community through their full participation and at a cost that the community and country can afford to maintain at every stage of their development in the spirit of self-reliance and self-determination. It forms an integral part of both of the country's health system of which it is the central function and main focus, and of the overall social and economic development of the community. It is the first level of contact of individuals, the family and community with the national health system, bringing health care as close as possible to where people live and work, and constitutes the first element of continuing health care process" (World Health Organization, 1985).

\section{Local authority}

A local authority is the service unit within a community in accordance with the national policy and legislative requirements.

\section{Perceptions}

Perceptions are the perceived views, expectations and fears of roleplayers within a selected local authority. An expectation in this study refers to the perceived and expressed needs and desires of the managers within a local authority in relation to the transformation of primary health care services. A fear is a negative psychological emotion perceived, experienced and expressed by managers when they feel threatened by unknown situations within a local authority in relation to the transformation of primary health care services.

\section{Strategy}

A framework for transformational management and leadership within a primary health care service in Gauteng.

\section{Research design}

A qualitative, exploratory and descriptive research strategy was used within the context of a local authority in Gauteng, based on the premise that there is not just a single reality and that reality is based on perceptions that are different for each person and that these perceptions change over time. What we know has meaning within a given situation or context (Burns \& Grove, 1993:61). Primary health care services had to be taken over by the local authority and there are certain dynamics (views, expectations and fears by the different roleplayers) impacting on the process of transformation.

The population consisted of the health care professionals employed by the local authority in a total of 11 clinics in one of the following managerial positions: Medical Officer of Health, Deputy Medical Officer of Health, Nursing Service Manager, Chief Community Health Nurse and Assistant Chief Community Health Nurse. A stratified purposive and theoretical sampling method was used (Burns \& Grove, 1993:239. 246) to include the managers who were employed at the local authority during the time of the study. The following inclusion criteria were stated:

* managers are in a full time and permanent post for at least three years with active involvement in the process of transformation during the time of the study and interviews; * availability for the interviews with proven proficiency in English.

A semi-structured interview was used as data-collection method (Cassell \& Symon, 1994:14-16). The following questions were asked during the interview:

* what are your expectations with regard to the taking over of primary health care services previously rendered by the provincial service, in a local authority?

* what are your fears in relation to the process of transformation within the local authority?

* what strategies could be employed to ensure successful transformation?

The interviews were conducted by an independent consultant. Informed written consent was obtained from the Medical Officer of Health as well as from the individuals themselves prior to the interviews. The rights of the participants were respected in relation to privacy, confidentiality and anonymity, self determination during the interview, fair treatment with protection from discomfort and harm. The quality of the research was facilitated by adhering to the ethical principles of nursing research (Denosa, 1998).

Tape recordings of the interviews were transcribed, followed by a content analysis in accordance with the principles described by Kerlinger (1986:447-483). Trustworthiness of the research was ensured by counteracting the threats (Woods 
Table 1 Distribution of categories: expectations, fears and strategies

\begin{tabular}{|c|c|c|c|c|c|}
\hline Expectations & $\mathbf{N}$ & Fears & $\mathbf{N}$ & Strategies & $\mathbf{N}$ \\
\hline Adequate staff & 9 & Conditions of service & 9 & Meetings/consultation & 6 \\
\hline Community satisfaction & 8 & Shortage of medication & 9 & Conditions of service/salaries & 6 \\
\hline Salaries/parity & 7 & Shortage of staff & 7 & Training of managers & 6 \\
\hline Stocks/supplies & 7 & Lack of supervision & 6 & Medications & 5 \\
\hline Job satisfaction & 6 & Resistance to change & 5 & Additional space & 3 \\
\hline Quality service & 5 & Inadequate facilities/space & 4 & Community participation & 2 \\
\hline Staff training & 5 & Loss of positions & 3 & Evaluation & 2 \\
\hline Consultation & 5 & & & & \\
\hline Community participation & 4 & & & & \\
\hline Support/relationship with regional office & 3 & & & & \\
\hline Devolution of power and responsibilities & 2 & & & & \\
\hline
\end{tabular}

\& Catanzaro, 1988:136) as follows:

* the status of the researcher was clarified and the context of the research delineated;

* the tape recorded interviews were verbatimly transcribed;

* an independent researcher and consultant was utilised for conducting the interviews;

* the participants' selection criteria were defined and adhered to;

* representivity of all roleplayers within the context of management was ensured;

* the results were confirmed by the participants and an independent researcher;

* the results were exposed to a literature control.

\section{Results}

The results are discussed in relation to the sample realisation, the perceptions (expectations and fears) of managers (table one) and a strategy for transformation management within the local authority (see figure one).

\section{Sample realisation}

A total of ten individual interviews were conducted, representative of all five areas within the local authority and representing all categories of managers within the population. It appeared as if the data was saturated on completion of these ten interviews.

\section{Expectations}

The expectations of managers were classified into the following categories: staff, community satisfaction, salaries/parity, stocks/supplies/medicines, job satisfaction, quality service delivery, consultation, community participation, support/relationship with regional office and the devolution of power and responsibility. Most of the participants $(\mathrm{N}=9)$ identified adequate staff as an important expectation and pre-requisite for the transformation of primary health care services. Selected direct quotations are as follows: "One thing we certainly expect is to have extra staff." "We can't be expected to render more services with less manpower." "What I am anticipating is to have more resources; staff to man these services - enough staff." "Naturally this would mean to have adequate staff." Transformation and quality service delivery is just not possible without adequate and competent staff. There is a great need for the appropriate redistribution of human resources to ensure successful implementation of the primary health care strategy and this is confirmed in the White Paper on the transformation of the health system in South Africa (1997:42) and in the Policy for the development of a district health system in South Africa (1995:14).

Community satisfaction was highlighted $(\mathrm{N}=8)$ as an important expectation for successful transformation of the clinic: "When we take over, all the health needs of the community should be met." "The problems of the clients - the patientsshould be addressed holistically." "The service should be acceptable to the community."'We have to accommodate the needs of the people we serve." The service providers need to meet the health needs of the community and monitor the level of community satisfaction (Oakley, 1989; South Africa, 1995:2-5; South Africa, 1997:64). An emphasis was also placed on equal salaries and parity and was viewed by the participants $(\mathrm{N}=7)$ as a serious concern during the take-over process as there were differences in salaries, not only on racial grounds but also in terms of provincial versus local authority service delivery authorities: "There are vast differences between the salaries paid by the local authorities and the salaries paid by provinces and this is gonna create big problems." "If we could only get to the point of equal salaries and equal conditions of service, people would settle down." "The salary issue is a very serious problem - not only the disparities between racial groups, but also between province and local authority." One of the legacies of the past can be seen in the disparities in relation to salaries and conditions of service that need to be rectified and be compliant with the labour rights and labour legislation of the country (South Africa, 1995:13).

Adequate stocks and supplies, especially enough medication, for successful transformation was also highlighted $(\mathrm{N}=7)$ as 
Figure 1: Conceptual framework: Transformation management of primary health care services in a local authority

\begin{tabular}{|c|c|c|}
\hline \multicolumn{3}{|c|}{ LEGISLATIVE FRAMEWORK } \\
\hline \multicolumn{3}{|c|}{$Q U A L I T Y$} \\
\hline Structure & Process & Outcome \\
\hline $\begin{array}{l}\text { Systems } \\
* \text { service delivery } \\
* \text { community participation } \\
* \text { communication: internal and } \\
\text { external } \\
\text { Material Resources } \\
* \text { operational budget } \\
\text { * adequate facilities/space } \\
* \text { appropriate equipment } \\
* \text { mobile clinics } \\
* \text { community health centres } \\
* \text { main (fixed) clinic } \\
\text { Drugs / supplies } \\
* \text { adequate drugs } \\
* \text { adequate stocks/supplies } \\
\text { Human Resources } \\
* \text { adequate staff }\end{array}$ & $\begin{array}{l}\text { Primary Health Care Management } \\
* \text { strategic plan } \\
* \text { participative } \\
* \text { decentralisation } \\
\text { Community Participation: } \\
* \text { empowerment } \\
* \text { decision-making } \\
* \text { partnerships } \\
\text { Human Resource Management: } \\
* \text { staffing } \\
* \text { utilisation } \\
* \text { development } \\
* \text { fair labour practice }\end{array}$ & $\begin{array}{l}\text { Primary health care: } \\
* \text { accessibility } \\
* \text { equity } \\
* \text { appropriateness } \\
* \text { acceptability } \\
* \text { effectiveness/efficiency } \\
\text { Community: } \\
\text { * satisfaction } \\
* \text { health care indicators } \\
\text { Human Resources: } \\
* \text { fair labour practices } \\
* \text { job satisfaction } \\
* \text { productivity }\end{array}$ \\
\hline \multicolumn{3}{|c|}{ Transformation management and leadership } \\
\hline & POLICY FRAMEWORK & \\
\hline
\end{tabular}

an important expectation: "We just don't have enough medication and other supplies to render a service." "We should get the resources - enough drugs, equipment, stocks etc." "We need adequate amounts of medicine and other resources to be able to render a good primary health care service." Adequate stocks and supplies is a obvious necessity for the delivery of quality health care services.

Job satisfaction was also raised as an expectation by six participants: "We really expect to start with, that there will be job satisfaction." "We musn't forget the staff that will be exposed to all of this - job satisfaction is therefore important." "Transformation is good if it brings about more job satisfaction." This desire might have been expressed as a fear due to uncertainties during the process of transformation. McMahon, Barton \& Piot (1992:45) states that primary health care service providers need to receive special attention due to the circumstances they work in and extra effort should be made to facilitate job satisfaction amongst these service providers.
Some participants $(\mathrm{N}=5)$ were of the opinion that transformation can only be successful if the quality of service delivery was improved: "High standard of care is important." "Many staff members are not capable of rendering quality care." "The idea is good, provided quality is what we want to achieve." "We should be fully equipped to render quality care." Quality service delivery is dependent upon structure, process and outcome. Adequate structure standards should be in place (both human and material resources) to enable quality professional services to be rendered (Muller, 1998:242). Quality is never negotiable.

Staff training was viewed $(\mathrm{N}=5)$ as an important aspect of transformation: "The training for primary health care nurses is too slow - we need well trained primary health care nurses." "The staff need to be adequately trained for the take-over process - especially in primary health care." "I just hope that they will speed up the training of primary health care nurses." Appropriate, adequate and timeous human resource development is important (South Africa, 1997:54; McMahon et al., 1992:89). 
Half of the participants $(\mathrm{N}=5)$ were of the opinion that consultation was important as part of the take-over process: "They must come to the people who are supposed to deliver the services in this take-over." "Like free health services - it was just decided without any consultation at the level of service delivery." "We had a lot of problems when free health services was announced because there was no consultation." "We are just told to take over without knowing what we have to do." Appropriate communication, which includes consultation with the service providers, is a prerequisite for any process of change/transformation. This should be seen as one of the most important principles of change/transformational management. Likewise, community participation is also viewed as important $(\mathrm{N}=4)$ : "We have to encourage community participation." "Adjustments will be necessary for us if we are really going to get community participation." "The community is being told to go to a clinic and you will get free service - they don't have a say in all of this." Consultation with all stakeholders are important during the process of transformation of primary health care services in South Africa (McMahon et al., 1992:57; South Africa, 1995:41).

The support from and a sound relationship with the Regional Office was also identified as an expectation ( $\mathrm{N}=3)$ : "We were told that the Regional Office will be there temporarily and their purpose is just to see us into the transformation process." "We will need help in the restructuring of a district." "We really hope the MEC will really look into the problems we foresee." The support of district-based management by the Regional Management is confirmed in the policy document on District Services (South Africa, 1995:57), especially in relation to the financial and administrative resources. The devolution and development of power and responsibility was expressed as an important expectation by the participants - they have to be empowered to fulfill their obligations: "Presently we are experiencing a problem ... it appears as if the province is not ready to devolve yet, not really letting go but to control everything as they don't seem to have much faith in the local authorities." "The other thing is primary health care is now devolved to a local authority and it should be easier to monitor and manage ... it will be easier to run - but we must be given the power and authority to do it." The devolution of power is confirmed by the Policy for the development of a district health system in South Africa (1995:46) and this principle should therefore be executed with the necessary empowerment of the management at the local authorities. The decision makers at grassroots level should be authorised to make decisions. This is also confirmed by McMahon et al. (1992:22). The devolution of power is a prerequisite for successful transformation of primary health care services.

\section{Fears}

The fears related mainly to the following: conditions of services, shortage of medication and staff, lack of supervision, resistance to change, inadequate space and facilities, as well as the existing positions. Most of the participants ( $N=9$ ) were afraid to loose what they have in terms of conditions of service:"We have different conditions of service and salaries." "People are afraid of loosing their benefits - waiting to see what is going to happen." "The problem is integration - not only integration of services, but us - what will happen?" Shortage of medication was once again mentioned as a specific fear that results in a feeling of frustration and powerlessness. "We are not happy with the EDL." "The biggest logistical problem is drugs - we just don't have enough." "The community were told that they can get free health services - but we don't have the drugs." "They should seriously consider this thing of drugs." "My fear is now - patients come to the clinic but we don't have drugs to treat them." Shortage of staff was also expressed as a fear $(\mathrm{N}=7)$ : "Yes - we have lots of fears - especially shortage of staff." "My heart is palpitating because my first fear is I don't have enough staff." "We now have more work and less staff." Most of the participants $(\mathrm{N}=6)$ also expressed the lack of supervision/authority, as well as the resistance to supervision, as a fear. "The people from the province - they won't listen to us; they don't want to work under us." "They are afraid of loosing their positions and their powers." Fears were also expressed towards inadequate space and facilities to deal with all the demands.

Resistance to change was obviously also expressed as a fear by many of the participants $(\mathrm{N}=5)$ : "There is this resistance - people don't want to come together." "They are afraid of now being inferior and resist the change." "There is a lot of resistance from the other parties." Resistance to change is not a new phenomena and has to be managed with sensitivity. Most of these fears are addressed in the White Paper on the transformation of the health system in South Africa (1997:57) and the Policy for the development of a district health system in South Africa (1995:14). It is clear that many of the expectations were mirrored in the fears.

\section{Transformation strategy}

The views of the participants on the strategy for transformation management, focused mainly on the following: meetings/consultation, conditions of service and salaries, training of managers, adequate medication/stocks, additional space, community participation and evaluation. Most of the expectations and fears that were expressed, were addressed as expectations and recommendations to be included in the transformation strategy. A few direct quotations are given: "The staff will have to sit down and workshop how they would like the services to be run." "Involve the people at grass root level." "Frequent meetings and consultations are important." "The possible loss of positions and existing conditions of service will have to be addressed."Training of staff to cope with the changes ..." "Adequaie facilities - mobile clinics, community health centres ... and of course enough drugs." "We need to involve the community more."

Although the internal factors impacting on the transformation of primary health care services in a local authority were explored, there are also external factors, such as the political strategies, legislation, economy, national policies, of which the White Paper on the transformation of the health system in South Africa (1997) and the Policy for the development of a District system in South Africa (1995) are most significant.

\section{Concluding statements: perceptions}

The expectations and fears of the management, as well as their perceptions on the transformation strategy, can be clas- 
sified as structure, process and outcome (see figure one):

* structural dimensions: there should be systems in place to enable quality service delivery, community participation and effective communication, adequate facilities and equipment is necessary, adequate material resources (especially medication) and adequate human resources (numbers and competencies);

* process dimensions: there should be quality processes in relation to the management of primary health care services, community participation (consultation/communication), quality human resource management and quality change/ transformational management;

* outcomes dimensions relate to: quality primary health care service delivery management (accessibility, acceptability, equity, appropriateness, efficiency/effectiveness), community satisfaction and evidence of improved health care outcomes, quality human resource management (fair labour practices and job satisfaction) and to achieve the underlying philosophy of transformation in South Africa.

\section{A strategy for transformation management of primary health care services in a local authority}

The conceptual framework for transformation management of primary health care services in a local authority is illustrated in figure one. The strategy (framework for transformation) is presented in relation to the context, the roleplayers, the goal/objectives and the process of transformation management and leadership.

\section{Context}

The context is the primary health care services within selected local authorities in Gauteng. There are both external and internal forces and dynamics to take into consideration. The local authorities function under the auspices of local government. Local government in South Africa has been undergoing significant changes. The Constitution (South Africa, 1996a) gives expanded responsibilities to local government and new policies are being implemented which should change the way municipalities function. The changes in local government will have a significant influence on the health sector, for local government currently delivers some health services and will play an important role in the district health system. The local government should mobilise communities and facilitate interaction between different roleplayers in the health sector, such as national government, the provincial government and the private sector (Fast \& Engelbrecht, 1999:45). Local government will therefore play an important role in the transformation of the local authorities. District municipalities are responsible for integrated development planning, provision of bulk infrastructure which includes health services and the promotion of equitable distribution of resources (Fast \& Engelbrecht, 1999:48).

The legislative and policy framework for the transformation of local authorities to deliver quality primary health care services, constitutes at least the following: Constitution (South Africa, 1996a), the White Paper for the transformation of the health system in South Africa (1997), Policy for the development of a health district system in South Africa, (1995), the Local Government Transition Act (South Africa, 1996b), as well as the current various labour laws and policies. This framework will impact on the structural transformation, i.e. resources (such as facilities, equipment, stocks/supplies and medication, human and other material resources, management systems and structures), the transformation of processes (primary health care service delivery, management processes, including resource management), that will hopefully result in the required outcomes of quality primary health care service delivery, adequate community satisfaction with improved health care indicators, as well as fair labour practices, job satisfaction and productivity as far as the employees are concerned.

A strategy for transformation management of primary health care services in relation to the context, includes at least the following:

* the context of the primary health care service is clearly identified and described in relation to the location of the service, service delivery profile, community profile and staff profile;

* the policy and relevant legislation framework is delineated, listed and analysed, indicating the impact thereof on the primary health care service;

* the contextual changes/transformation required within the primary health care service, is clearly delineated in preparation for the strategic transformational plan to be designed.

\section{Roleplayers}

The roleplayers in this process of transformation are the managers and other service providers at national, provincial and local/district levels (the employers and employees) and the community. It is obvious that each group of roleplayers have certain expectations during the process of transformation. The nursing service managers have also expressed many fears. It is therefore important to counteract the fears and to meet/ address the expectations in accordance with the contextual circumstances and legislative/policy framework.

There is a strong trend towards decentralisation in South Africa and tremendous demands are being placed upon the local government sphere, but local government cannot always meet these demands. It is in this context that the District Health System is established. The process of developing such a system must take account of the local government reality and the various processes that will impact on the health service delivery. It is therefore important for people involved in the health sector at district/local level to participate in the formation of integrated development plans, to explore new mechanisms for delivering of services, to engage with the allocation of health service functions to district and local municipalities and to continue and improve the rendering of high quality health care in an integrated manner (Fast \& Engelbrecht, 1999:49).

Role clarification of roleplayers is necessary during the process of transformation. This role clarification should take into account the mission of a transformed health service at local level (South Africa, 1997:13) to focus on the following:

* to provide a primary health care service that is more 
appropriate, equal, acceptable and effective;

* to provide leadership and guidance during the process of transformation and primary health care service delivery;

* to promote and monitor the health of all people in South Africa.

The roleplayers should be empowered with regard to their role, the process and principles of transformation and transformational leadership, as well as to the quality related issues of structure, process and the outcomes that need to be achieved (Rathwell, et al., 1995; Streefland \& Chabot, 1990). A strategy for the transformation of primary health care services accommodates at least the following in relation to the roleplayers:

* all relevant roleplayers are identified and listed;

* a profile analysis of the roleplayers is undertaken;

* there is a strategy for empowerment and leadership development of the different roleplayers;

* there is a clear role-clarification of roleplayers during the process of transformation;

* there is evidence of adequate empowerment/development of the roleplayers in relation to their responsibilities during the process of transformation;

* there is a human resource transformation management strategy to facilitate fair labour practices during the process of transformation within the primary health care service.

\section{Goal/objective}

The goal is to transform the present delivery of health services in order to be compliant with the National Health Plan (South Africa, 1997). The objective is quality transformational management to achieve the following:

* quality management of primary health care service delivery (accessibility, equity, appropriateness, acceptability and efficiency/effectiveness) resulting in the improvement of existing health care indicators within the community;

* quality community participation resulting in community satisfaction;

* quality human resource management resulting in fair labour practices, job satisfaction and productivity.

The goals/objectives of the primary health care service in relation to the transformation process is therefore identified and clearly formulated for inclusion into the strategic/transformational plan.

\section{The process of transformation management and leadership}

The process of transformation management relates to the management of primary health care service delivery (structure, process and outcome), community participation and human resource management. The principles of planned change/transformation management and leadership should be applied throughout (Brooke, 1990; Schulz \& Johnson, 1990; Marriner-Tomey, 1993; Barker, 1990).

\section{Management of primary health care service delivery}

A transformational strategic plan is necessary to guide the process of transformation and quality service delivery within the primary health care services. Successful transformation is also dependent upon the participation of all the relevant roleplayers to facilitate ownership and accountability by all concerned. Therefore a decentralised management system is necessary with adequate empowerment of all the relevant decision-makers (Schulz \& Johnson, 1990). A functional integration of comprehensive primary health care services is of paramount importance. This includes at least the following: a situational analysis of the existing services rendered by the primary health care service and an analysis of those services to be taken over by the primary health care service that were traditionally rendered by the provincial service. An analysis of the existing structures, processes and outcomes in relation to the transformational requirements also needs to be undertaken.

\section{Community participation}

Creative strategies to involve the community at decision-making levels, have to be developed and applied. This would relate to at least the following:

* an analysis of existing community participation, intersectoral partnerships and leadership practices;

* a needs analysis of community expectations, leadership, strengths and weaknesses;

* the establishment and/or strengthening of consultation/ decision-making structures within the community;

* a strategy/operational plan to enable adequate community participation and communication between the community and the primary health care service;

* adequate representation of the various community groups/roleplayers, such as non-governmental organisations, youth groups, church/religious groups, ward councillors, traditional healers, civics, woman's organisations, disabled groups, etc.

* empowerment of the community;

* implementation and evaluation of community participation strategies/plans to result in adequate and effective partnerships between the community and the primary health care services.

\section{Human resource management}

The process of transformation has created many fears in relation to human resource management. A human resource management strategy should therefore be part of the strategic plan to facilitate appropriate staffing of the primary health care services, adequate utilisation of staff, relevant development/empowerment of the staff, as well as fair labour practices in accordance with the relevant labour laws of the country. An adequate skills mix is necessary for the rendering of quality and cost-effective primary health care services. This will require a situational analysis of the existing skills mix and the needs of the primary health care service in accordance with the national, provincial and local policy frameworks.

\section{Principles of transformation management and leadership}

Transformation management is the facilitation of change within the individual, group and organisation/primary health care service to meet the transformational needs and demands within the internal and external environment. This process 
consists of three steps, i.e. initiation of the transformation process, the change strategy itself and stabalisation (Drake, 1993:72). The initiation phase focuses on the following: creation of an awareness for transformation/change by highlighting the internal realities and external forces impacting on the primary health care services. This necessitates the creation of a dynamic communication system and process between the various roleplayers within the primary health care service and externally (Flarey, 1995:4). This process is embodied in the internal and external assessment phases during the design of a strategic and transformational plan for the service. The change strategy would include a revision of the vision $/ \mathrm{mis}$ sion statements of the primary health care service, the objectives of transformation, as well as the operational plan for the attainment of each objective (Schulz \& Johnson, 1990:62). The transformational/change strategy must focus on at least the following (see figure one):

* Structural transformation: transformation in relation to the systems, facilities/equipment, drugs/supplies and other material resources, as well as the human resources within the primary health care service;

* Process transformation: in relation to the process of primary health care management, community participation and human resource management;

* Outcomes: systems to enable the monitoring and evaluation of the outcomes in relation to the quality of primary health care service delivery, community and human resource outcomes.

The process of change is re-inforced by evaluation, monitoring, positive feedback, constructive criticism, encouragement and empowerment. The general principles of transformation management and leadership should accommodate at least the following (Schulz \& Johnson, 1990); Marriner-Tomey, 1993; Drake, 1993) :

* dynamic communication with all roleplayers: the establishment, implementation and continuous evaluation of communication structures and strategies;

* empowerment through participation of all the relevant roleplayers: the process of transformation;

* managing resistance to change;

* leadership development;

* resource management.

The third step in transformation management refers to the stabilisation phase (Drake, 1993). The process of transformation is very labour intensive and emotional. It is therefore necessary to enter into a phase of stabilisation once the objectives have been attained. During this phase emphasis is placed on the successes and the less successful outcomes are addressed.

The transformation strategy in relation to the process of transformation management and leadership, should therefore include at least the following:

* a transformational/strategic plan on the structural dimensions (systems, facilities/equipment, drugs/supplies and human resources); the process of primary health care management, community participation and human resource management required for successful transformation of the primary health care service and the required outcomes;

* a transformation/strategic plan on the general management of change/transformation to foster ownership and successful transformation and to counteract resistance to change.

\section{Conclusions and recommendations}

The following conclusions are made:

* the managers have the following expectations: adequate human resources, community satisfaction, adequate stocks, supplies, medication, space/facilities to deliver quality primary health care services, fair labour practices in terms of equity/parity of salaries and other conditions of services, job satisfaction, quality service delivery with appropriate devolution of power/authority, consultation with service providers and consultation with the community, adequate human resource development, support from regional offices;

* the fears relate to the identified expectations as well as to resistance of change and loss of positions;

* a transformation strategy needs to focus on the expectations and counteract the fears, in accordance with the principles of change/transformational management;

* the expectations and fears are classified within the dimensions of structure, process and outcome;

* a strategy for transformation management of primary health care services in a local authority was developed. focusing on the context, the roleplayers, the objectives, the process of transformation management and leadership, as well as the outcomes.

The following recommendations are made:

* the formulation of standards for transformation management in health services;

* the evaluation of the quality of transformation management within the primary health care service after implementation of the standards/strategy.

\section{Concluding remarks}

The transformation of primary health care services in a local authority is not only a very labour intensive process, but is also an emotional process resulting in lots of expectations and fears by the roleplayers. This process of transformation needs to be carefully designed, implemented and continuously evaluated. This article explored and described the perceptions (expectations and fears) of managers within a primary health care service in a local authority during the process of transformation. A strategy (transformational framework) was presented to accommodate the perceptions, focusing on a process of planned transformation management and leadership.

\section{Acknowledgements}

All the managers that participated in this research, despite their existing workload, are thanked for their contribution and valuable time. 


\section{References}

BARKER, AM 1990: Transformational nursing leadership. Baltimore: Williams and Wilkens.

BURNS, N \& GROVE, SK 1993: The practice of nursing research. Conduct, critique \& utilization; second edition. Philadelphia: WB Saunders.

BROOKE, A 1990: Managing change. London: MacMillan.

COODINGTON, DC; CHAPMAN, CR \& POKOSKIE, KM 1996: Making integrated health work. Colorado: Englewood.

CASSELL, C \& SYMON, S 1994: Qualitative methods in organizational research: a practical guide. London: Sage.

DENOSA 1998: Ethical standards for nurse researchers. Pretoria: DENOSA.

DRAKE, JM 1993: Veranderingsbestuur in 'n verpleegdiens. Johannesburg: RAU.

FAST, H \& ENGELBRECHT, B 1999: Local Government Transformation: a guide for health workers. Hospital and Nursing Yearbook for Southern Africa; 39th revised edition. Pretoria: Pharmaceutical Printers and Publishers.

FLAREY, DL 1995: Redesigning and nursing care delivery, transforming our future. Philadelphia: Lippincott.

KERLINGER, F 1986: Foundations of behavioural research. New York: Rinchart and Winston.

MARRINER-TOMEY, A 1993: Transformational leadership. St Louis: Mosby.

McMAHON, R; BARTON, E \& PIOT, M 1992: On being in charge: a guide to management in primary health care. Geneva: World Health Organization.

MULLER, ME 1998: Nursing Dynamics; second edition. Durban: Heinemann.

OAKLEY, P 1989: Community involvement in health development: an examination of the critical issues. Geneva: WHO.

RATHWELL, TO; GODINHO, J \& GOTT, M 1995: Tipping the balance towards primary health care. Aldershot: Averbury.

SCHULZ, R \& JOHNSON, AC 1990: Management of hospitals and health services: Strategic issues and performance; third edition. St Louis: Mosby.

SOUTH AFRICA 1995: A policy for the development of a district health system for South Africa. Pretoria: Department of Health.
SOUTH AFRICA 1996a: Constitution of the Republic of South Africa (Act no. 105 of 1996). Pretoria: State Press.

SOUTH AFRICA 1996b: Local Government Transition Act (Act no. 9 of 1996). Pretoria: State Press.

SOUTH AFRICA 1997: White Paper for the transformation of the health system in South Africa (Notice No. 667 of 1997). Pretoria: State Press.

STREEFLAND, P \& CHABOT, J 1990: Implementing primary health care: experiences since Alma-Ata. Amsterdam: Royal Tropical Institute.

WOODS, NF \& CATANZARO, M 1988: Nursing Research. Theory and Practice. St Louis: CV Mosby.

WORLD HEALH ORGANIZATION 1985: Health manpower requirements for the achievement of health for all by the year 2000 through primary health care (Technical Report Series, 717). Geneva: WHO. 